DOI https://doi.org/10.30525/978-9934-26-073-5-2-3

\title{
ЖАНРОВІ ОЗНАКИ РОМАНУ ВИХОВАННЯ У ТВОРАХ МАЛКОЛМА БРЕДБЕРІ І ДЖОНА ФАУЛЗА
}

\author{
Назаренко Н. I.
}

кандидат філологічних наук, дочент кафедри англійської філології

Маріупольського державного університету

\author{
Дацер К. С. \\ старший викладач кафедри \\ «Менеджмент і підприємництво на морському транспорті» \\ Азовського морського інституту \\ Національного університету «Одеська морська академія» \\ м. Маріуполь, Донещька область, Украӥна
}

Здатність жанру роману до різноманітних трансформацій обумовлює інтерес літературознавців до проблеми типологізації романних різновидів. Такий жанровий різновид роману, як роман виховання або Bildungsroman (термін Ф. Бланкенбурга), що виник у Німеччині у XVIII столітті, шляхом культурної інтеграції потрапляє до інших національних літератур, переосмислюється і продовжує свій художній розвиток до нашого часу. Дослідженню генези та еволюції роману виховання, його структури, своєрідності художньої та філософської природи присвятили увагу М. Бахтін, В. Дільтей, Д. Затонський, Ф. Мартіні, І. Влодавська, В. Зарва, В. Пашигорєв, С. Притолюк, О. Чик та багато інших. Структура роману виховання містить елементи інших жанрових різновидів роману - пригодницького, шахрайського, соціально-психологічного, філософського, сатиричного, подорожі. М. Бахтін стверджує, що роман виховання $є$ синтетичним романом, підготовленим розвитком роману подорожі, роману випробувань, біографічного [1, с. 202]. I. Влодавська зазначає, що «хронотоп роману виховання $\epsilon$ типологічно стійким, підпорядковуючись головній організуючій ідеї учнівства у життя, реалізація якого можлива тільки у часовій та просторовій протяжності» [4, с. 4].

У переломні епохи світовідчуття та самовідчуття героя посилюються, внаслідок чого митці XX століття приділяють велику увагу психологічному аналізу. Взаємодія молодої людини з соціальним і культурним середовищем, набуття нею інтелектуального, емоційного та практичного 
досвіду, участь у цьому процесі наставника (позитивного або негативного персонажа) - ці компоненти складають психологічний аспект виховання індивіда. У постмодернізмі, глобальному художньому явищі межі XX-XXI століть, виокремлюються такі основні ознаки, як інтерес до художнього минулого людства, прагнення до рівноправного діалогу старого та нового, захопленість цитуванням, перерозподілом, грою, пародіюванням традиції, сприйняття світу як хаосу, естетика симулякрів, подвійне кодування, маргінальність, багаторівневість побудови тексту та його смислів. У постмодерністській літературі межі численних жанрових різновидів роману часто невиразні, внаслідок чого багато британських письменників 70-80-х років поділяли «<..> принцип еклектизму, рухаючись між реалізмом, експериментом і сучасним романом» [2, с. 357].

«Маг» Дж. Фаулза («The Magus», 1966) і «Професор Кримінале» М. Бредбері («Doctor Criminale», 1992), на наш погляд, є зразками постмодерного синтетичного роману, де вдало сполучені елементи роману виховання і роману випробувань (ініціації), детективної історії і трансформованої пікарески, забарвлені іронією та інтертекстуальністю. По-перше, в обох творах на рівні сюжетної організації тексту реалізовано мотив мандрів / шляху-дороги. Молоді герої, обидва з університетською освітою, - Ніколас Ерфе у Фаулза та Френсіс Джей у Бредбері залишають Англію і вирушають у «широкий світ». Цим новим світом для Ерфе стала Греція, тоді як Джею довелося мандрувати по багатьох європейських країнах і хронотоп дороги стає основним принципом побудови сюжету. Різного роду пригоди і зустрічі, погоня за невловимим філософом, любовні інтриги і обмани - все це, як і в шахрайському романі, випробує молодий, досить наївний «журнець», як він сам себе іронічно називає, під час своєї подорожі.

По-друге, під час подорожі (мандрів), під впливом різних чинників відбувається процес еволюції ціннісно-світоглядної позиції персонажів. Поворотними моментами, які виявляють їх перехід в «іншу якість», стають ситуації вибору, випробування; збіги, що мають символічний характер; «доленосні» сюжетні зустрічі. Інші персонажі виконують конструктивну чи деструктивну функцію в становленні героїв, допомагаючи добрими настановами, розумінням або влаштовуючи перепони на шляху, стаючи при цьому недоброзичливцями або навіть ворогами, що примушує рухатися вперед, шукати виходи зі складних ситуацій. I тому наступною спільною рисою означених романів вважаємо наявність образу «вчителя» / наставника. В обох творах діють контрастні пари головних героїв: молода, достатньо наївна людина навчена життєвим досвідом, старша за віком, відома i, до того ж, досить 
заможна особистість. Ніколас Ерфе, потрапивши до «магічного театру», який влаштував для нього Моріс Кончіс, найбагатший мешканець грецького острова, проходить через декілька болісних обрядів-вистав (ініціацій) і в фіналі роману повертається до Англії, до реального життя, втративши ілюзіі, але отримавши нове розуміння світу. В романі М. Бредбері опозицію складають початківець-тележурналіст Френсіс Джей і «найбільший мислитель сучасності» Басло Кримінале. Журналіст сам іронічно підкреслює цей контраст: «Він - колос, реактивний двигун знання; я - патагонський пігмей. Він - класик ери модернізму; я - пляма постмодерністської смути»; «Він був слон, а я - блоха» [3]. Але, крім цього, на наш погляд, цю опозицію можна також схарактеризувати за ознакою «шахрай - простак». Завершивши своє розслідування, набувши життєвого і політичного досвіду, Френсіс приходить до усвідомлення того, що «найбільший філософ сучасності, флагман світової науки», який «обертався серед вершків мистецтва і влади», по суті був зручним посередником між Заходом i Сходом в фінансових i політичних махінаціях.

Підсумовуючи, зазначимо, що жанровими ознаками роману виховання в романах «Маг» Дж. Фаулза i «Професор Кримінале» М. Бредбері є мотив мандрів, мотив випробувань / ініціацій, наявність негативного «наставника» та динамізм характерів молодих героїв. Особистості головних персонажів не $\epsilon$ статичними образами, вони змінюються під впливом різноманітних психологічних, соціокультурних і політичних чинників.

\section{Література:}

1. Бахтин М. Эстетика словесного творчества. М.: Искусство, 1979. 424 c.

2. Бредбері М. Британський роман нового часу. К.: Ксенія Сладкевич, 2011. 480 с.

3. Брэдбери М. Профессор Криминале [Электронный ресурс]. Режим доступа: http://royallib.com/book/bredberi_malkolm/professor kriminale.html.

4. Влодавская И. А. Поэтика английского романа воспитания начала XX века: типология жанра. К.: Вища школа, 1983. 181 с.

5. Фаулз Дж. Маг. Харків: Книжковий Клуб «Клуб сімейного дозвілля», 2016. 528 с. 